\title{
Endoftalmitis yang dinduksi penggunaan lensa kontak - Laporan kasus
}

\author{
${ }^{1}$ Ade J. Nursalim, ${ }^{2}$ Herny Poluan
}

\author{
${ }^{1}$ Program Studi Ilmu Kesehatan Mata Fakultas Kedokteran Universitas Sam Ratulangi \\ Manado \\ ${ }^{2}$ KSM Ilmu Kesehatan Mata RSUP Prof. Dr. R. D. Kandou Manado. \\ Email: dr.adejn@gmail.com
}

\begin{abstract}
Nowadays, the popularity of contact lens increases progressively, not only in refractive anomaly correction but also in fashion purposes. Albeit, among contact lens wearers, there is a tendency of the occurence of eye infection, especially the cornea. We reported a 13year-old female that came to the Eye Departement of Prof. Dr. R. D. Kandou Hospital Manado with the main complaint of blurred left eye since a week ago. Physical examination resulted in normal right eye and its visual acuity was within normal limit (6/6). Examination of the left eye resulted in visual acuity of 1/300, palpebral blepharospasm, conjunctival and ciliar injections, anterior stromal defect of $3 \times 5 \mathrm{~mm}$ in the cornea, and hypopion $<1 \mathrm{~mm}$ in the anterior chamber. The ultrasound examination showed spreading aggregations and turbidity of the vitreous body. This patient was diagnosed as emmetropia of the right eye and contact-lens-induced endophthalmitis of the left eye. The therapy consisted of tobramycin, artificial tears, polyvinylpyrrolidone, vitamin $\mathrm{C}$, mefenamic acid, and chlorpheniramine maleate tablet. Although there was improvement of visual acuity and clinical signs during 8-day hospitalization, the prognosis was good for ad vitam but poor for functionam and sanationam. This case indicates that education to the contact lens wearers is still needed even in this modern era.
\end{abstract}

Keywords: contact lens, endophthalmitis

\begin{abstract}
Abstrak: Dewasa ini, lensa kontak mengalami peningkatan popularitas yang pesat, bukan saja dalam hal kelainan refraksi tetapi juga untuk keperluan mode. Pemakaian lensa kontak berisiko terjadinya infeksi pada mata, terutama kornea. Kami melaporkan seorang perempuan berusia 13 tahun, datang ke Poliklinik Ilmu Kesehatan Mata, RSUP Prof. Dr. R. D. Kandou Manado dengan keluhan pandangan mata kiri kabur sejak satu minggu lalu. Pada pemeriksaan fisik ditemukan mata kanan (OD) dalam batas normal dengan visus 6/6. Pada mata kiri (OS) didapatkan visus $1 / 300$, blefarospasme palpebra, injeksi konjungtiva dan silier, pada kornea terdapat defek $1 / 3$ anterior stroma dengan ukuran $3 \times 5 \mathrm{~mm}$, dan pada kamera okuli anterior terdapat hipopion setinggi $<1 \mathrm{~mm}$. Hasil pemeriksaan USG dari OS menunjukkan gambaran agregat yang menyebar dan kekeruhan vitreus. Pasien didiagnosis dengan emetropia okuli dekstra dan endoftalmitis okuli sinistra yang diinduksi penggunaan lensa kontak. Terapi yang diberikan ialah antibiotika tobramisin, artificial tears, polyvinylpyrrolidone, vitamin $\mathrm{C}$, asam mefenamat, dan klorfeniramin maleat tablet. Pasien mengalami perbaikan visus dan gejala klinis selama delapan hari rawat inap. Prognosis pasien tergolong baik untuk prognosis ad vitam tetapi tergolong buruk untuk functionam dan sanationam. Kasus ini mengindikasikan bahwa edukasi terhadap pengguna lensa kontak tetap diperlukan dalam era modern ini.
\end{abstract}

Kata kunci: lensa kontak, endoftalmitis

Thomas Young pada tahun 1801 pertama kali memperkenalkan lensa kontak terbuat dari lilin yang dapat dilengketkan pada korena dan memungkinkan kelopak mata untuk berkedip. Sejak itu, bahan pembuatan lensa kontak mengalami evolusi dan 
berkembang menjadi poly methyl methacrylate (PMMA).

Penggunaan lensa kontak terus mengalami peningkatan popularitas. Lensa kontak bukan hanya digunakan untuk memperbaiki kelainan refraksi, akan tetapi juga untuk keperluan mode. Seiring dengan peningkatan penggunaan lensa kontak, peningkatan insidens kejadian infiltratif kornea pun semakin meningkat. Kelsy et al. pada tahun 2017 melaporkan bahwa insidensi infiltrasi kornea simtomatik akibat penggunaan lensa kontak lama berkisar 2,5-6\%. Namun, angka ini bisa mengalami peningkatan hingga $20-25 \%$ jika kejadian infriltratif kornea akibat penggunaan lensa kontak panjang yang asimtomatik dimasukkan. Temuan ini lebih tinggi dibandingkan laporan 10 tahun lalu oleh Stapleton et al. yaitu angka kejadian infiltratif kornea simtomatik paling tinggi 3,3\% namun lebih rendah untuk kejadian yang asimtomatik yaitu paling tinggi mencapai $44 \%$ per tahun. $^{2}$

Penggunaan lensa kontak merupakan faktor risiko paling sering untuk infeksi kornea di negara berkembang. Insidensi infeksi kornea yang disebabkan lensa kontak mencapai $1 / 3$ dari kunjungan ke Departemen Gawat Darurat Mata. ${ }^{3}$ Infiltrasi kornea akibat lensa kontak memiliki gejala klinis yang beragam, mulai dari mata kemerahan hingga infeksi kornea dengan ekskavasi ke epitel kornea, lapisan Bowman, dan stroma yang berakibat nekrosis jaringan. Jika hal ini terus berlanjut, dapat mengakibatkan endoftalmitis. Komplikasi penggunaan lensa kontak dapat dikategorikan kedalam beberapa etiologi, yaitu infeksi, metabolik, toksik, mekanik, inflamasi, dan dry eyes. ${ }^{4}$

Berikut ini dilaporkan kasus endoftalmitis yang disebabkan penggunaan lensa kontak jangka panjang.

\section{LAPORAN KASUS}

Seorang perempuan berusia 13 tahun datang ke Poliklinik Ilmu Kesehatan Mata, RSUP Prof. Dr. R. D. Kandou Manado dengan keluhan pandangan mata kiri kabur yang dialami sejak satu minggu lalu.
Awalnya pasien menggunakan lensa kontak selama 2 hari, tidak dilepaskan saat tidur dan tidak pernah dibersihkan. Lensa kontak pasien merupakan jenis lensa kontak untuk sekali pakai, tidak memiliki ukuran, dan hanya digunakan untuk keperluan kosmetik. Pasien memiliki kebiasaan menggunakan lensa kontak dan tidak dilepaskan selama tidur. Pagi hari setelah pasien terbangun, mata kiri pasien terasa nyeri, gatal, dan kabur. Mata kiri pasien berwarna merah, terasa silau, dan berair. Tidak terdapat nyeri pada pergerakan mata dan demam.

Pasien kemudian melepas lensa kontak dan memeriksakan diri ke puskesmas setempat, diberikan obat tetes mata sebanyak satu buah. Pasien tidak mengingat jenis obatnya. Dua hari setelah diberikan obat tetes, pasien merasa penglihatan semakin kabur hingga hanya dapat melihat pada jarak sekitar 4 meter. Pasien kemudian memeriksakan diri kembali ke puskesmas dan mendapat rujukan ke rumah sakit.

Di rumah sakit, pasien diberikan obat tetes mata levofloksasin dan artificial tears. Dua hari setelahnya pasien merasa semakin kabur. Penglihatan pasien menurun hingga hanya dapat melihat bayangan tangan disertai rasa nyeri hebat serta mata merah dan berair. Tidak terdapat nyeri pada pergerakan mata. Pasien merasa demam, tidak enak badan dan tidak ada nafsu makan.

Pasien mengeluhkan bagian depan matanya berwarna putih pekat. Pasien kemudan memeriksakan diri kembali ke rumah sakit dan dirujuk ke RSUP Prof. Dr. R. D. Kandou untuk penanganan lebih lanjut. Saat tiba di rumah sakit, pasien masih merasa kabur serta mata merah dan berair. Pasien juga merasa silau dan nyeri kepala yang hilang timbul terutama ketika masuk ke ruangan yang terang. Tidak terdapat nyeri pada pergerakan mata, riwayat penggunaan kacamata obat, atau masalah mata sebelumnya. Tidak ada anggota keluarga yang menderita penyakit serupa. Pasien memiliki kuku tangan yang panjang dan kotor.

Hasil pemeriksaan fisik pada pasien ini ditemukan mata kanan (okuli dekstra; OD) 
dalam batas normal dengan visus $6 / 6$. Visus mata kiri (okuli sinistra; OD) $1 / 300$, serta terdapat blefarospasme palpebra, injeksi konjungtiva dan silier, pada kornea terdapat defek $1 / 3$ anterior stroma dengan ukuran $3 x$ $5 \mathrm{~mm}$. Pada kamera okuli anterior (camera oculi anterior; COA) terdapat hipopion setinggi $<1 \mathrm{~mm}$. Iris, pupil, dan lensa sulit dievaluasi. Hasil pemeriksaan ultrasonografi $B$ scan mendapatkan gambaran agregat yang menyebar dan kekeruhan vitreus. Gerak bola mata baik ke segala arah. Tidak terdapat nyeri pada pergerakan bola mata (Gambar 1)

Berdasarkan anamnesis, pemeriksaan klinis, dan pemeriksaan penunjang, pasien didiagnosis dengan emetropia OD dan endoftalmitis OS. Pasien diberikan tatalaksana non medikamentosa dan medikamentosa. Kuku pasien dipotong dan dibersihkan, kemudian pasien diberikan edukasi pemotongan kuku, cara mencuci tangan, serta kebersihan tangan dan mata. Pasien diberikan tetes mata tobramisin satu tetes per 2 jam, artificial tears 6 kali 1 tetes sehari, polyvinylpyrolidone $2 \% 6$ kali 1 tetes sehari, vitamin $\mathrm{C}$ tablet 2 kali $50 \mathrm{mg}$ sehari, klorfeniramin maleat tablet 3 kali 4 mg sehari. Pasien dirawat inapkan dan dilakukan pemantauan pemberian obat dan follow up setiap hari. Prognosis penglihatan pada pasien ini dubia ad malam.

Follow up hari ke-2, pasien mengeluhkan mata kiri terasa gatal dan berwarna merah. Visus OS masih 1/300 disertai blefarospasme tetapi pada segmen anterior hipopion di COA telah menghilang. Struktur di segmen anterior bola mata masih sulit dievaluasi. Pasien didiagnosis dengan emetropia OD dan ulkus kornea OS. Pengobatan dilanjutkan.

Follow up hari ke-5, pasien mengeluhkan mata kiri terasa gatal. Visus OS menjadi 1/60. Blefarospasme serta injeksi konjungtiva dan silier berkurang. Tidak terdapat hipopion di COA. Struktur di segmen anterior bola mata masih sulit dievaluasi. Pasien didiagnosis dengan emetropia OD dan ulkus kornea OS. Pengobatan dilanjutkan (Gambar 2).

Follow up hari ke-8, pasien mengeluh- kan mata kiri terasa gatal. Visus OS menjadi 2/60. Tidak terdapat injeksi konjungtiva dan silier. Tidak terdapat hipopion di COA. Struktur di segmen anterior bola mata masih sulit dievaluasi. Pasien didiagnosis dengan emetropia OD dan ulkus kornea OS (Gambar 3). Asam mefenamat dihentikan. Dosis tobramisin diturunkan menjadi 6 kali sehari. Pasien dianjurkan untuk rawat jalan dan kontrol ke Poliklinik Ilmu Kesehatan Mata tiga hari kemudian.

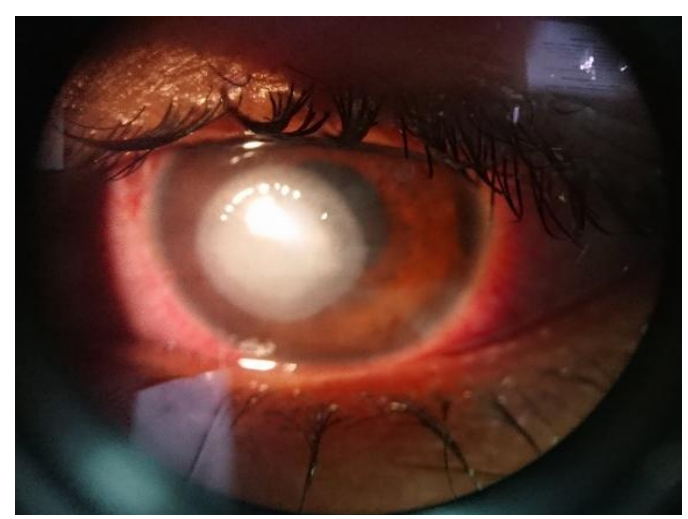

Gambar 1. Foto mata kiri pasien pada kunjungan pertama (hari ke-1)

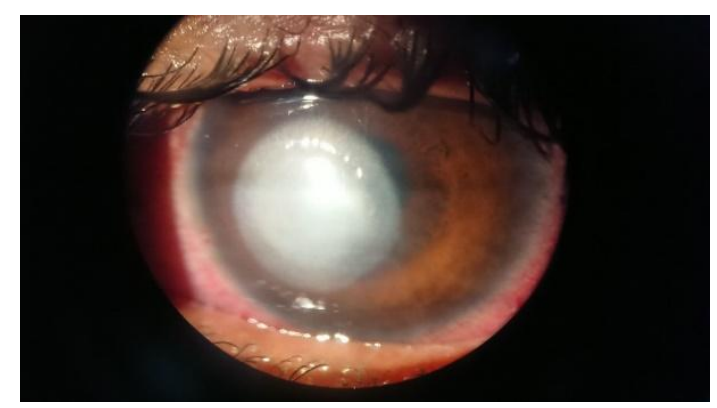

Gambar 2. Foto mata kiri pasien pada followup hari ke-5

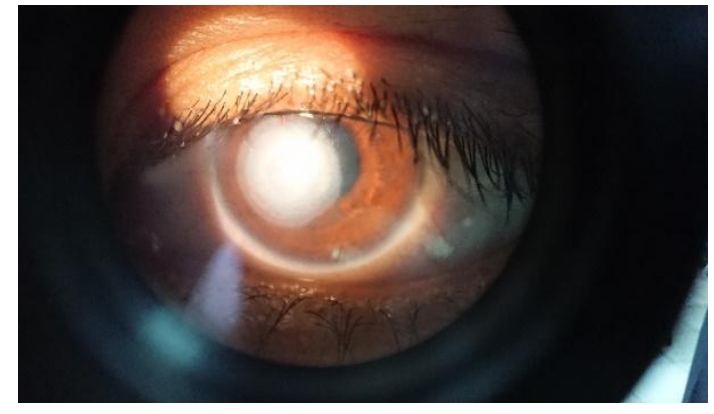

Gambar 3. Foto mata kiri pasien pada followup hari ke-8 


\section{BAHASAN}

Pasien datang dengan keluhan pandangan mata kiri kabur sejak 1 minggu lalu. Kaburnya mata pasien disertai dengan mata kemerahan, silau, dan berair. Keluhan ini diawali dengan penggunaan lensa kontak saat pasien tidur. Lensa kontak merupakan faktor predisposisi yang sering terjadi pada kasus keratitis bersamaan dengan trauma, obat tetes mata yang terkontaminasi, mekanisme defens yang tidak sempurna, dan kerusakan struktur dari permukaan kornea. ${ }^{3}$

Pasien menggunakan lensa kontak tipe harian. Penelitian epidemiologi menunjukkan $0,21 \%$ individu yang menggunakan lensa kontak tipe jangka panjang mengalami keratitis ulseratif lebih banyak daripada pengguna lensa kontak tipe harian yang mencapai $0,02 \%$. Peningkatan risiko terjadinya keratitis ulseratif meningkat sekitar 15 kali lipat pada pasien yang menggunakan lensa kontak selama tidur malam dan risiko menjadi berkali-kali lipat pada hari-hari setelahnya tanpa dilepaskan. ${ }^{3}$

Pasien merasa nyeri pada matanya disertai gatal dan kabur di pagi hari setelah lensa kontak dipakai semalaman. Progres dari gejala ini bergantung pada virulensi dari organisme yang menginfeksi. Progres penyakit yang cepat sering disebabkan oleh Pseudomonas aeruginosa. Pasien datang dengan visus $1 / 300$, defek korena $1 / 3$ anterior stroma serta ukuran sekitar $3 \times 5 \mathrm{~cm}$ disertai injeksi silier. Temuan ini sesuai dengan karakteristik Pseudomonas aeruginosa yang sering menunjukkan gejala nekrosis dengan permukaan tidak rata serta sekret eksudat lengket dan mukopurulen. Bakteri ini juga sering menimbulkan hipopion seperti yang terjadi pada pasien ini.

Hipopion yang didapatkan pada pemeriksaan slit lamp pasien ini sesuai untuk ulkus kornea infeksius, endoftalmitis, dan iridosiklitis. Ultrasonografi dilakukan untuk menyingkirkan diagnosis banding. Hasil pemeriksaan ultrasonografi pada pasien ini menunjukkan vitreus hiperekoik, mobil, dan padat pada segmen posterior bola mata dengan diagnosis akhir endoftalmitis okuli sinistra. ${ }^{5}$
Penatalaksanaan pasien ini terdiri atas non-medikamentosa dan medikamentosa. Penatalaksanaan non-medikamentosa disini berupa edukasi untuk memotong kuku pasien. Kuku pasien yang terlihat kotor dan panjang meningkatkan risiko infeksi pada mata jika menggaruk saat mata terasa gatal dan merupakan faktor predisposisi terjadinya keratitis. ${ }^{6}$ Pasien juga diajarkan cara mencuci tangan untuk mengurangi jumlah organisme patogen pada tangannya, menjaga kebersihan mata, dan menyeka mata dengan tisu sekali pakai.

Penatalaksanaan medikamentosa pada pasien ini berupa pemberian antibiotika tobramisin, artificial tears, polyvinyl pyrrolidone bersama vitamin A dan natrium hialuronat, vitamin $\mathrm{C}$, asam mefenamat dan klorfeniramin maleat tablet. Pemilihan tobramisin dilakukan sesuai dengan kedokteran berbasis bukti yang terbukti dapat menembus biofilm dari Pseudomonas aeruginosa. $^{6,7}$

Polyvinylpyrrolidone sebagai antibakteri dikombinasikan dengan vitamin A dan natrium hialuronat diberikan pada pasien ini. Sebuah artikel pada tahun 1986 melaporkan bahwa vitamin A dapat mempercepat penyembuhan luka. ${ }^{8,9}$ Pemberian natrium hialuronat sendiri lebih populer untuk dry eye syndrome dan xerophthalmia. ${ }^{10}$ Penelitian meta-analisis dari Ang et al. ${ }^{11}$ yang mencakup 18 clinical trials menunjukkan efikasi natrium hialuronat dalam mengatasi gejala dry eye syndrome. Hal ini disebabkan bahan ini berefek memperbaiki kualitas air mata. ${ }^{10,11}$

Pada pasien ini juga diberikan vitamin $C$ yang diperlukan untuk pembentukan kolagen, fungsi imun yang baik, dan sebagai antioksidan jaringan, ${ }^{12}$ serta dapat membantu meningkatkan permeabilitas dan bioavailabilitas dari obat tetes mata. ${ }^{13}$ Asam mefenamat diberikan 3x500 mg untuk mengurangi nyeri yang dirasakan pasien. ${ }^{14}$ Klorfeniramin maleat tablet diberikan untuk mengurangi rasa gatal pada pasien dan efek kantuknya dapat membantu pasien untuk beristirahat. ${ }^{1}$

Prognosis pasien ini tergolong baik yaitu ad vitam. Hilangnya hipopion pada 
COA menunjukkan penurunan proses infeksi, tetapi fungsi penglihatan sulit pulih sempurna dan kemungkinan besar terbentuk jaringan parut. Graft kornea mungkin dapat dipertimbangkan untuk dilakukan pada pasien ini. Faktor risiko primer yang perlu dipertimbangkan dalam melakukan graft kornea antara lain adanya kalat inflamasi lama atau glaukoma. Keratoplasti lamelar dan penetrating dapat dipertimbangkan pada pasien ini. ${ }^{3}$

\section{SIMPULAN}

Kami melaporkan kasus seorang perempuan berusia 13 tahun dengan endoftalmitis okuli sinistra yang diinduksi oleh penggunaan lensa kontak. Diagnosis ditegakkan berdasarkan anamnesis dan pemeriksaan kedua mata, serta pemeriksaan slit lamp dan USG okuli sinistra. Pasien didiagnosis dengan emetropia okuli dekstra dan endoftalmitis okuli sinistra. Terapi yang diberikan ialah antibiotika tobramisin, artificial tears, polyvinylpyrrolidone, vitamin $\mathrm{C}$, asam mefenamat, dan klorfeniramin maleat tablet. Pasien mengalami perbaikan selama perawatan dengan prognosis tergolong baik untuk ad vitam tetapi tergolong buruk untuk functionam dan sanationam.

\section{DAFTAR PUSTAKA}

1. Efron N. Contact Lens Practice E-Book. Elsevier Health Sciences, 2016; p. 3.

2. Steele KR, Szczotka-Flynn L. Epidemiology of contact lensinduced infiltrates: an updated review. Clin Exp Optom. 2017;100(5):473-81.

3. American Academy of Ophthalmology. External diseases and cornea, In: Basic and Clinical Science Course. Section 8. Italy: American Academy of Ophthalmology, 2015; p. 146-7.

4. American Academy of Ophthalmology. Clinical optics. In: Basic and Clinical Science Course. Section 3. Italy: American Academy of Ophthalmology, 2015; p. 185-7.

5. Bagheri N, Wajda B, Calvo C, Durrani A. The Wills Eye Manual: Office and Emergency Room Diagnosis and Treatment of Eye Diseases. China: Lippin- cott Williams \& Wilkins, 2016; p. 35.

6. Gault J, Vanderf JF. Ophthalmology Secrets in Color. USA: Elsevier, 2016; p. 75.

7. Walters MC, Roe F, Bugnicourt A, Franklin MJ, Stewart PS. Contribution of antibiotic penetration, oxygen limitation and low metabolic activity to tolerance of Pseudomonas aeruginosa biofilm to ciprofloxacin and tobramycin. Antimicrob Agents Chemoter. 2003;47(1);317-23.

8. Kim J, Pitts B, Stewart PS, Camper A, Yoon J. Comparison of the antimicrobial effects of chlorine, silver ion, and tobramycin on biofilm. Antimicrob Agents Chemother. 2008; 52(4):144653.

9. Hunt TK. Vitamin A and wound healing. JAAD. 1986;15(4):817-21.

10. Hung VC, Lee JY, Zitelli JA, Hebda PA. Topical tretinoin and epithelial wound healing. Arch Dermatol. 1989;125(1): 65-69.

11. Ang BCH, Sng JJ, Wang PXH, Htoon HM, Tong LHT. Sodium hyaluronate in the treatment of dry eye syndrome: asystematic review and meta-analysis. Sci Rep. 2017;7(1):9013.

12. Kong X, Yan C, Ma W, Li Y, Xing B, Yang Y, et al. Sodium hyaluronate's effect on xerophthalmia: a meta-analysis of randomized controlled trials. Curr Med Res Opin. 2016;32(3):477-84.

13. MacKay D, Miller AL. Nutritional support for wound healing. Altern Med Rev. 2003;8(4):359-77.

14. Khurana V, Vadlapudi AD, Vadlapatla RK, Pal D, Mitra AK. Functional characterization and molecular identification of vitamin $\mathrm{C}$ transporter (SVCT2) in human corneal epithelial (HCEC) and retinal pigment epithelial (D407) cells. Curr Eye Res. 2015; 40(5):457-69.

15. National Center for Biotechnology Information. PubChem Compound Database; CID=4044. [cited 2017 Sept 24]. Available from: https: //pubchem. ncbi.nlm.nih.gov/compound/4044

16. National Center for Biotechnology Information. PubChem Compound Database; $\mathrm{CID}=2725$. [cited 2017 Sept 24]. Available from: https: //pubchem. ncbi.nlm.nih.gov/compound/2725. 